\title{
Konsep Pengenaan Pajak Alat Berat Pasca Putusan Mahkamah Konstitusi Nomor 15/PUU-XV/2017
}

\author{
Dahliana Hasan \\ Fakultas Hukum Universitas Gadjah Mada Yogyakarta Indonesia \\ Jln. Socio Justitia Bulaksumur Yogyakarta Indonesia 55281 \\ dahliana.hasan@mail.ugm.ac.id
}

Received: 24 Oktober 2020; Accepted: 23 Mei 2021; Published: 25 Agustus 2021

DOI: 10.20885/iustum.vol28.iss3.art3

\begin{abstract}
Abstact
Constitutional Court Decision No. 15/PUU-XV/2017 opens up opportunities for the imposition of taxes on heavy equipment with a new legal basis through amendments to Law no. 28 of 2009 on Regional Taxes and Levies. Therefore, legislators need to think about the right concept of tax on heavy equipment, especially with regard to the environmental impacts caused as a result of its operation. This is a normative legal research using case study and conceptual approaches wtih qualitative analysis. This study concludes that the proposed heavy equipment tax concept is directed at restructuring the fuel tax policy and formulating a new concept for heavy equipment tax or registration fees that can become agents of pollution behavior change. However, both legislators and executors need to anticipate the main challenges that may arise in restructuring and implementing the tax policy.
\end{abstract}

Key Words: Agent of change; heavy equipment; tax

Abstrak

Putusan Mahkamah Konstitusi No. 15/PUU-XV/2017 membuka peluang bagi pengenaan pajak atas alat berat dengan dasar hukum baru melalui perubahan Undang-Undang No. 28 Tahun 2009 tentang Pajak Daerah dan Retribusi Daerah. Oleh karena itu, pembentuk undang-undang perlu untuk memikirkan konsep pajak atas alat berat yang tepat terutama berkenaan dengan dampak lingkungan yang ditimbulkan sebagai akibat pengoperasiannya. Penelitian ini merupakan penelitian hukum normatif dengan menggunakan pendekatan kasus dan konseptual serta analisis secara kualitatif. Penelitian ini menyimpulkan bahwa usulan konsep pajak alat berat diarahkan pada restrukturisasi kebijakan pajak bahan bakar dan penyusunan konsep baru atas pajak atau bea registrasi alat berat yang dapat menjadi agen perubahan perilaku pencemaran. Namun, legislator maupun eksekutor perlu mengantisipasi tantangan utama yang mungkin timbul dalam restrukturisasi dan implementasi kebijakan pajak tersebut.

Kata-kata Kunci: Alat berat; pajak; agen perubahan 


\section{Pendahuluan}

Pajak terhadap alat berat menjadi polemik di kalangan masyarakat terutama pengusaha alat berat di sektor pertambangan, kehutanan dan perkebunan sejak diundangkannya Undang-Undang Nomor 28 Tahun 2009 tentang Pajak Daerah dan Retribusi Daerah (UU PDRD). Alat berat dalam UU a quo dimasukkan ke dalam jenis kendaraan bermotor sehingga dapat dibebani dengan pajak. ${ }^{1}$ Pajak ini dipungut oleh pemerintah daerah provinsi dengan sebutan Pajak Kendaraan Bermotor (PKB). Alokasi dari hasil penerimaan PKB ini paling sedikit 10\% (sepuluh persen) ditujukan untuk pembangunan dan/atau pemeliharaan jalan serta peningkatan moda dan sarana transportasi umum. ${ }^{2}$

Bagi pemerintah daerah, PKB merupakan salah satu sumber pendapatan daerah terbesar selain Bea Balik Nama Kendaraan Bermotor (BBN-KB) dan Pajak Bahan Bakar Kendaraan Bermotor (PBB-KB). Tahun 2018 PKB di seluruh provinsi Indonesia menempati urutan pertama penerimaan pajak dari kendaraan bermotor (PKB, BBN-KB dan PBB-KB) yang mencapai 44,8\% dari total penerimaan sebesar Rp. 96.700.000.000.000,00.3 Dominasi penerimaan pajak dari kendaraan bermotor tersebut berbeda jika dilihat dari lanskap wilayah, yaitu wilayah pertambangan ${ }^{4}$ misalnya di Kalimantan Timur yang cenderung rendah dibandingkan dengan PBB-KB. ${ }^{5}$

Proporsi penerimaan PKB yang cenderung rendah di wilayah pertambangan di Indonesia tersebut salah satunya dipicu oleh Putusan Mahkamah Konstitusi Nomor 15/PUU- XV/2017 tentang uji materi Undang-Undang Nomor 28 Tahun 2009 tentang Pajak Daerah dan Retribusi Daerah. Putusan Mahkamah Konstitusi tersebut mengabulkan gugatan dari pihak penggugat yang mendalilkan bahwa alat berat tidak lagi ditempatkan dalam definisi kendaraan bermotor berdasarkan UU PDRD. 6 Dasar Mahkamah Konstitusi mengabulkan permohonan tersebut mengacu pada Putusan Mahkamah Konstitusi Nomor 3/PUU-XIII/2015 tentang

\footnotetext{
${ }^{1}$ Pasal 1 Angka 13 Undang-Undang Nomor 28 Tahun 2009 tentang Pajak Daerah dan Retribusi Daerah.

2 Pasal 8 Ayat (5) Undang-Undang Nomor 28 Tahun 2009 tentang Pajak Daerah dan Retribusi Daerah.

3 Choirunnissa Nur, Melimpah Kendaraan Melimpah Pendapatan, https://lokadata.id/artikel/ melimpah- kendaraan-melimpah-pendapatan, diakses pada tanggal 3 April 2020.

${ }^{4}$ Ibid.

${ }^{5}$ Ibid.

${ }^{6}$ Putusan Mahkamah Konstitusi Nomor 15/PUU-XV/2017 tentang uji materi Undang-Undang Nomor 28 Tahun 2009 tentang Pajak Daerah dan Retribusi Daerah.
} 
uji materi Undang-Undang Nomor 22 Tahun 2009 tentang Lalu Lintas dan Angkutan Jalan yang menyatakan bahwa Penjelasan Pasal 47 ayat (2) huruf e bagian c 1 UU LLAJ tidak lagi mempunyai kekuatan hukum mengikat sehingga alat berat bukan termasuk kendaraan bermotor. Selain itu, dalam amar putusannya Mahkamah Konstitusi juga memerintahkan kepada pembentuk undang-undang dalam jangka waktu 3 tahun untuk melakukan perubahan terhadap UU PDRD, khususnya berkenaan dengan pengenaan pajak terhadap alat berat.

Terdapat beberapa diskursus terhadap Putusan Mahkamah Konstitusi Nomor 15/PUU- XV/2017 tepatnya berkaitan dengan pungutan PKB dan BBNKB alat berat. Ni Nyoman Tanti Parwati dan I Wayan Parsa dalam tulisannya menyatakan bahwa pemerintah tidak lagi dapat melakukan pungutan pajak alat berat dengan keluarnya Putusan Mahkamah Konstitusi a quo yang sifatnya final dan binding atau erga omnes.7 Tulisan tersebut sejalan dengan pendapat pengusaha atau pemilik alat berat di Indonesia bahwa alat berat bukan obyek kendaraan bermotor pasca Putusan Mahkamah Konstitusi Nomor 15/PUU-XV/2017 sehingga PKB dan BBN-KB tidak lagi dapat ditagihkan kepada pemilik alat berat. ${ }^{8}$

Pemerintah sendiri dengan mengacu pada pertimbangan hakim dalam putusan a quo menafsirkan bahwa pemungutan PKB dan BBN-KB terhadap alat berat masih dapat dikenakan dalam tenggang waktu 3 tahun berdasarkan ketentuan UU PDRD yang lama selama belum diundangkannya perubahan terhadap UU tersebut. 9 Namun demikian, dalam praktiknya pemilik atau pengusaha alat berat cenderung abai terhadap penegasan pemerintah sehingga Pemungutan PKB dan BBN-KB terhadap alat berat menjadi tidak efektif. ${ }^{10}$

${ }^{7}$ Ni Nyoman Tanti Parwati dan I Wayan Parsa, 2018, Implikasi Yuridis Putusan Mahkamah Konstitusi Nomor 15/PUU-XV/2017 Terhadap Alat Berat Sebagai Obyek Pajak Ganda, Jurnal Ilmu Hukum, No. 3, Vol. 7, Februari 2019, hlm. 14.

8 Agus Sahbani, Pembentuk UU Diminta 'Rombak' Pengaturan Pajak Alat Berat, https://www.hukumonline.com/berita/baca/lt59dc955430b47/pembentuk-uu-diminta-rombak-pengaturanpajak-alat-berat, diakses pada 3 April 2020. Lihat juga dalam: Puja Rizqy R. dan Abdul Hasyim B., "Analisis Kontribusi Pemungutan Pajak Alat-Alat Berat dalam Meningkatkan PAD di Provinsi Sumatera Utara", Jurnal Perpajakan, No. 2, Vol. 1, 2020, hlm. 125.

9 Hadijah Alayidrus, Pajak Alat Berat: Pemerintah Tetap Pungut Pajak Selama Masa Transisi, https:/ / finansial.bisnis.com/read/20171012/10/698647/pajak-alat-berat-pemerintah-tetap-pungut-pajakselama-masa-transisi, diakses pada 3 April 2020.

${ }_{10}$ Muhammad Fauzi Aditya, "Efektivitas Pelaksanaan Pemungutan Pajak Kendaraan Bermotor Khusus Alat Berat Dan Alat Besar Di Kabupaten Temanggung”, Skripsi, Fakultas Hukum Universitas Gadjah Mada. Lihat juga dalam: Koran Kaltara, 2019, BPPRD Akui Kesulitan Menarik Pajak Alat Berat, http://korankaltara.com/bpprd-akui-kesulitan-menarik-pajak-alat-berat/, diakses pada akses 3 April 2020. 
Hal menarik untuk dicermati dalam Putusan Mahkamah Konstirusi tersebut adalah pertimbangan Hakim yang menegaskan bahwa meskipun frasa pasalpasal dalam UU PDRD tersebut dinyatakan inkonstitusional, tidak berarti bahwa alat berat tidak dapat dikenakan pajak, oleh karena itu dibutuhkan dasar hukum baru untuk mengenakan pajak terhadap alat berat. Pertimbangan hakim tersebut sejalan dengan pendapat awal dari para pemohon uji materi yang menyatakan tidak berkeberatan adanya pungutan terhadap alat berat selama norma dan aturannya jelas. ${ }^{11}$ Beranjak dari kedua hal tersebut membuka peluang bagi pemerintah untuk memikirkan konsep yang tepat bagi pengenaan pajak terhadap alat berat di Indonesia.

Pajak secara teoritis dapat digunakan sebagai a tool of social engineering atau alat perubahan perilaku masyarakat. ${ }^{12}$ Pengenaan pajak dalam hal ini mengesampingkan fungsi utamanya sebagai pengisi kas negara atau penghimpun dana dari masyarakat. Keberhasilan dari pengenaan pajak untuk mengubah perilaku tersebut terletak pada pengesampingan fungsi anggaran yang dalam jangka panjang penerimaan dari pajak menjadi semakin sedikit atau berkurang. ${ }^{13}$

Konsep pajak pada praktik internasional yang dimaksudkan sebagai agen perubahan sudah dikenal luas baik di negara maju maupun negara berkembang. Konsep ini menekankan pada internalisasi biaya eksternalitas negatif yang timbul sebagai akibat aktivitas produksi dan/atau konsumsi. ${ }^{14}$ Hanya saja isu maupun tantangan yang dihadapi atas penerapan konsep tersebut sangat luas seperti dampak terhadap distribusi penghasilan sampai dengan lemahnya penegakan hukum. ${ }^{15}$

Peluang pengenaan pajak alat berat yang diberikan oleh Mahkamah Konstitusi perlu disikapi dengan bijak oleh Pemerintah dengan tidak lagi

${ }^{11}$ Lihat: Angka 92 Pokok Permohonan dalam Putusan Mahkamah Konstitusi Nomor 15/PUU-XV/2017 tentang uji materi Undang-Undang Nomor 28 Tahun 2009 tentang Pajak Daerah dan Retribusi Daerah.

12 Sony Devano dan Siti Kurnia Rahayu, Perpajakan: Konsep, Teori dan Isu, Prenada Media Group, Jakarta, 2006, hlm. 97.

${ }^{13}$ Kalle Maatta, Environmental Taxes: An Introductory Analysis, Edwar Elgar Publishing Limited, 2006, hlm. 96-97. Lihat juga dalam: Santoso Brotodihardjo, Pengantar Ilmu Hukum Pajak, Eresco Bandung, 1995, hlm. 206.

14 Andrew J. White, "Decentralised Environmental Taxation in Indonesia: A Proposed Double Dividend for Revenue Allocation and Environmental Regulation", Journal of Environmental Law, No. 1, Vol. 19, 2007, hlm. 47.

15 Organisation for Economic Co-operation and Development (OECD), The Political Economy of Environmentally Related Taxes, 2006, hlm. 67-149. 
bersandarkan pada dasar hukum yang lama dalam UU PDRD. Konsep ini perlu dirombak oleh pembentuk undang-undang in casu a quo Pemerintah bersama Dewan Perkilan Rakyat (DPR). Isu eksternalitas negatif yang ditimbulkan sebagai akibat pengoperasian alat berat ini menjadi menarik untuk dikupas untuk menjadi dasar pengenaan pungutan atau pajak. Oleh karena itu, konsep baru perlu diformulasikan sehingga dapat digunakan sebagai pertimbangan atau alas kebijakan.

Penelitian ini ditujukan untuk mengembangkan konsep pajak alat berat yang ideal untuk dikenakan di Indonesia dengan menggunakan teori-teori yang relevan terkait dengan pajak dan pungutan pencemaran. Namun, formulasi konsep pajak alat berat dalam penelitian ini terbatas pada konsep pungutan dari sisi hukum dan tidak diarahkan pada kalkulasi ekonomi. Selain itu, identifikasi dan analisis juga menyasar pada tantangan yang dihadapi dan mungkin timbul sebagai akibat penyusunan dan penerapan konsep pajak alat berat yang ditawarkan. Penelitian ini diharapkan dapat mengisi celah penelitian-penelitian sebelumnya terkait pajak atas alat berat dengan memberikan rekomendasi konsep pungutan baru kepada pemerintah. Lebih lanjut, penelitian ini diharapkan memberikan kontribusi terhadap perkembangan ilmu hukum khususnya bidang hukum pajak.

\section{Rumusan Masalah}

Penelitian ini mengangkat permasalahan sebagai berikut: Pertama, bagaimanakah konsep pungutan atas alat berat di Indonesia pasca Putusan Mahkamah Konstitusi Nomor 15/PUU-XV/2017 tentang uji materi UndangUndang Nomor 28 Tahun 2009 tentang Pajak Daerah dan Retribusi Daerah dalam rangka meminimalisir dampak lingkungan akibat pengoperasiannya? Kedua, bagaimanakah tantangan yang berpotensi timbul dalam penerapan konsep pungutan atas alat berat tersebut?

\section{Metode Penelitian}

Penelitian ini merupakan penelitian hukum normatif yang mengkaji dan mengembangkan konsep pungutan alat berat di Indonesia pasca Putusan 
Mahkamah Konstitusi Nomor 15/PUU-XV/2017 tentang uji materi UndangUndang Nomor 28 Tahun 2009 tentang Pajak Daerah dan Retribusi Daerah, serta tantangan yang mungkin timbul dalam penyusunan dan penerapan konsep tersebut. Pendekatan yang digunakan adalah pendekatan kasus (case approach) dan pendekatan konseptual (conceptual approach).

Pendekatan konseptual merupakan pendekatan utama yang dilakukan dengan mempelajari teori dan doktrin yang berkembang dalam ilmu hukum pada umumnya dan hukum pajak pada khususnya sehingga peneliti dapat menemukan pemikiran yang melahirkan konsep baru sesuai dengan isu yang diteliti. Pendekatan kasus digunakan karena penelitian ini menganalisis putusan pengadilan (Putusan Mahkamah Konstitusi Nomor 15/PUU-XV/2017) yang bersifat final dan mengikat.

Jenis data yang digunakan terdiri dari data sekunder mencakup bahan hukum primer, sekunder dan tersier. ${ }^{16}$ Bahan hukum tersebut didapat dari penelitian kepustakaan atau studi dokumen meliputi peraturan perundangundangan perpajakan maupun buku, jurnal, hasil penelitian, makalah dan dokumen-dokumen lainnya yang relevan dengan topik penelitian serta kamus hukum untuk memberikan kelengkapan informasi.

Data yang terkumpul disistematisasi dengan melakukan klasifikasi berdasarkan pokok bahasan, interpretasi dan penulisan teks narasi. ${ }^{17}$ Kegiatan tersebut dilakukan secara simultan dan merupakan pengertian dari analisis data kualitatif. ${ }^{18}$ Analisis tersebut kemudian dituangkan dalam bentuk deskripsi yang menggambarkan atau menghasilkan argumentasi maupun kerangka atau konsep baru untuk menjawab isu hukum yang diajukan.

16 Maria SW. Sumardjono, Pedoman Pembuatan Usulan Penelitian, Gramedia Pustaka Utama, Jakarta, 1997, hlm. 36. Lihat juga dalam: Soerjono Soekanto, Pengantar Penelitian Hukum, UI Press, Jakarta, 1986, hlm. 52.

${ }^{17}$ John W. Creswell, Research Design: Qualitative and Quantitative Approach, Sage Publication, London, 1994, hlm. 154.

18 Ibid. 


\section{Hasil Penelitian dan Pembahasan}

\section{Konsep Pungutan atas Alat Berat di Indonesia Pasca Putusan Mahkamah Konstitusi Nomor 15/PUU-XV/2017 untuk Meminimalisir Polusi Lingkungan}

Putusan Mahkamah Konstitusi Nomor 15/PUU-XV/2017 tentang uji materi Undang- Undang Nomor 28 Tahun 2009 tentang Pajak Daerah dan Retribusi Daerah hakikatnya memberi peluang kepada pembentuk undang-undang untuk melakukan perubahan terhadap UU PDRD dalam jangka waktu 3 tahun khususnya berkenaan dengan pengenaan pajak terhadap alat berat. Pendapat awal dari pemohon uji materi pun memperkuat bahwa pengenaan pajak terhadap alat berat tidak menjadi masalah dengan catatan selama norma dan aturannya jelas. Hal inilah yang kemudian perlu dianalisis dalam penelitian ini dengan menyajikan terlebih dahulu best practices mengenai pungutan terhadap alat berat atau yang dikenal dengan istilah "tax or excise or fee ${ }^{19}$ on heavy equipment" di beberapa negara.

\section{USA}

Durham County di North Carolina USA menerapkan pajak alat berat sejak 1 Januari 2009. Pajak ini ditujukan atas alat berat yang dibebankan pada penerimaan bruto dari properti dengan kriteria khusus. ${ }^{20}$ Kriteria khusus ini merujuk pada alat berat yang ditawarkan pada tingkat retail untuk penyewaan jangka pendek atau panjang dan dimiliki atau disewa oleh orang atau badan yang terlibat dalam bisnis penyewaan alat berat ke masyarakat. ${ }^{21}$ Jumlah pajak yang dibayar sebesar $1.2 \%$ untuk unit administrasi dari negara bagian/State (County) dan $0.8 \%$ untuk kota (municipalities) yang ditambahkan dalam jumlah pembayaran sewa alat berat kemudian diserahkan kepada pemungut pajak Durham County per tiga bulan sekali. ${ }^{22}$

Konstruksi pengenaan pajak alat berat yang sama dengan Durham County juga diterapkan oleh Cumberland County di North Carolina USA. Pengenaan

${ }^{19}$ Istilah tax or excise merujuk pada pengertian pajak, sedangkan istilah fee merupakan pungutan yang bersifat lebih umum. Lihat lebih lanjut dalam: Neha Pathakji, "Slippery Slopes of Compensatory Tax and Fee", Journal of the Indian Law Institute, No. 1, Vol. 56, Maret 2014, hlm. 78.

20 Durham County NC, Heavy Equipment, diunduh dari https://www.dconc.gov/government/ departments-f- z/tax-administration/collections-payments-billing/heavy-equipment, diakses 18 Agustus 2020.

${ }^{21}$ Ibid.

22 Ibid. 
pajak atas alat berat merupakan substitusi dari pajak properti untuk penyewaan alat berat yang diselenggarakan suatu perusahaan kepada masyarakat dengan tarif sebesar 1.2\% untuk unit administrasi dari negara bagian/State (County) dan $0.8 \%$ untuk kota (municipalities). ${ }^{23}$ Pemungutan pajak dibebankan pada perusahaan dengan kualifikasi $50 \%$ penghasilan perusahaan berasal dari penyewaan alat-alat berat. Pajak dipungut oleh perusahaan kepada konsumen yang menyewa alat berat untuk kemudian diserahkan kepada Cumberland County per tiga bulan sekali.24

\section{Australia}

Kepemilikan terhadap heavy vehicles dan heavy mobile machinery di negaranegara bagian Australia harus didaftar berdasarkan the National Motor Vehicle Regulation (NHVR) 2008.25 Peraturan tersebut berisi ketentuan biaya registrasi yang berlaku secara nasional dan disesuaikan setiap tahunnya dengan tujuan memulihkan biaya akibat penggunaan kendaraan berat di jalan raya. ${ }^{26}$ Semua kendaraan dan trailer dengan Massa Kendaraan Kotor (GVM) atau Agregat Trailer Massa (ATM) lebih dari 4,5 ton yang berusia tiga tahun atau lebih dari tanggal pembuatan akan diperiksa sebelum diregistrasi ulang dengan nama pemilik kendaraan baru di setiap negara bagian, kecuali terhadap bus dan kendaraan dengan tujuan khusus seperti traktor, peralatan pertanian dan pembuatan jalan. ${ }^{27}$ Beranjak dari penjalasan tersebut, dapat disimpulkan bahwa biaya registrasi didasarkan pada penggunaan alat berat dan trailer di jalan publik.

Ketentuan lain mengatur bahwa kendaraan untuk tujuan khusus seperti peralatan pemadam kebakaran, grader, fork lift, mobile crane, dan self-propelled mesin pertanian hanya akan dikenai biaya registrasi saat kendaraan tersebut berbasis truk atau kelebihan massa. ${ }^{28}$ Kewajiban registrasi pelat kendaraan berat diterbitkan secara nasional di Australia Capital Territory, New South Wales,

23 Cumberland County, Heavy Equipment, http://www.co.cumberland.nc.us/departments/taxgroup/tax/business-property/special-sales-tax/heavy-equipment, diakses pada 18 Agustus 2020.

${ }^{24}$ Ibid.

25 South Australia, Heavy Vebicle Registration Scheme, diunduh dari https://www.sa.gov.au/topics/drivingand- transport/heavy-vehicles/registering-a-heavy-vehicle/heavy-vehicle-registration-scheme, diakses 26 Agustus 2020.

${ }^{26}$ Ibid.

${ }^{27}$ Ibid.

${ }^{28}$ Ibid. 
Queensland, South Australia, Tasmania, Victoria dan, secara sukarela, di Northern Territory setiap kali:

a. kendaraan berat baru terdaftar;

b. kendaraan berat yang tidak terdaftar didaftarkan ulang;

c. pendaftaran negara bagian atau teritori ditransfer ke yurisdiksi selain Westren Australia;

d. pelat nomor yang hilang, rusak, hancur atau dicuri diganti. ${ }^{29}$

Tarif pelat ditetapkan secara nasional sebesar AUD 25.45 per set pelat pada 2019 dan akan ditinjau ulang oleh yurisdiksi setiap tahunnya serta dapat dinaikkan sejalan dengan inflasi. ${ }^{30}$

Pemerintah Australia memberikan fuel tax credits $^{31}$ (kredit pajak bahan bakar) untuk penggunaan bahan bakar terhadap alat berat baik yang digunakan di jalan umum ataupun di luar jalan umum. Bahan bakar yang dimaksud di sini adalah bahan bakar kena pajak seperti bahan bakar cair seperti solar, bensin atau campuran bahan bakar serta bahan bakar gas seperti gas petroleum cair (LPG), gas alam cair (LNG) dan gas alam terkompresi (CNG). ${ }^{32}$ Metode kalkulasi untuk mengklaim penggunaan bahan bakar alat berat disusun semudah mungkin dengan apportionment/pembagian antara penggunaan di jalan umum dan di luar jalan umum. ${ }^{33}$ Metode ini tidak berlaku untuk alat berat yang digunakan di luar jalan umum secara penuh seperti alat berat jenis grader, backhoe loader, front-end loader, wheeled excavator, forklift, wheeled bulldozer, fertiliser spreader, combine harvester, dan tractor. ${ }^{34}$ Klaim terhadap fuel credit atas jenis alat berat tersebut diberikan dengan tarif 'all other business uses' yang tidak perlu lagi dikurangi dengan biaya pengguna jalan. ${ }^{35}$

${ }^{29}$ NHVR, National Heavy Vehicle Plates, https://www.nhvr.gov.au/road-access/registration/nationalheavy- vehicle-plates, diakses pada 26 Agustus 2020.

${ }^{30} \mathrm{Ibid}$.

31 Skema fuel tax credit merupakan salah satu fuel scheme yang disediakan untuk mengurangi biaya yang dikeluarkan sebagai akibat penggunaan bahan bakar minyak yang ramah lingkungan. Klaim terhadap jumlah kredit bahan bakar bergantung pada kapan diperolehnya, jenis dan aktivitas penggunaannya. Insentif ini diperuntukkan bagi pemilik atau pengguna alat berat. Lihat: Australian Governmet-Australian Tax Office, Fuel Scheme, https://www.ato.gov.au/Business/Fuel-schemes/, diakses pada 28 September 2020.

32 Australian Taxation Office, Heavy Vehicles, https://www.ato.gov.au/printfriendly.aspx?url=/ Business/Fuel- schemes/In-detail/Heavy-vehicles/, diakses pada 26 Agustus 2020.

${ }^{33}$ Ibid.

${ }^{34}$ Ibid.

35 Ibid. 


\section{Singapura}

Pungutan terhadap kendaraan baru di negara Singapura disertai dengan pajak dan pungutan dalam hal ini biaya registrasi seperti biaya Pendaftaran (Registration Fee), Biaya Pendaftaran Tambahan (Additional Registration Fee), Kuota Premium untuk Sertifikat Kepemilikan (Quota Premium for a Certificate of Entitlement (CoE)), Pajak Jalan (Road Tax) dan Cukai (Excise Duty). ${ }^{36}$ Khusus machinery plant seperti forklift, drilling machine hanya membayar biaya registrasi sebesar SGD 220, namun untuk mixer beton dan semen (concrete and cement mixers), cranes dan pompa beton (concrete pumps) tetap dikenakan biaya pendaftaran tambahan, CoE kategori $\mathrm{C}$ atau $\mathrm{E}$ dan pajak jalan sesuai dengan kategori goods vehicles. ${ }^{37}$

Merujuk pada best practice di atas, pungutan terhadap alat berat cenderung pada pungutan dalam bentuk biaya registrasi seperti yang diterapkan di Negara Singapura dan Australia. Sementara itu, Alat berat di Negara USA tidak dikenakan pungutan baik dalam bentuk pungutan atau pajak. Hal yang menarik di Negara Australia adalah adanya kebijakan yang disebut dengan skema fuel tax credit dan cleaner fuels grants. ${ }^{38}$ Kedua skema tersebut hakikatnya menarik untuk dipertimbangkan karena menyediakan insentif bagi pengusaha atau bisnis yang menggunakan bahan bakar ramah lingkungan sehingga emisi yang diakibatkan oleh penggunaan bahan bakar dapat ditekan seminimal mungkin.

Merujuk konstelasi normatif pengenaan pajak alat berat di Indonesia dalam nomenklatur PKB dan BBN-KB pada hakikatnya sudah tidak tepat untuk diterapkan pasca putusan Mahkamah Konstitusi Nomor 15/PUU-XV/2017 tentang uji materi Undang-Undang Nomor 28 Tahun 2009 tentang Pajak Daerah dan Retribusi Daerah. Terlebih, Mahkamah Konstitusi telah memerintah kepada pembentuk undang-undang untuk melakukan perubahan terhadap UU PDRD

36 A Singapore Government Agency Website, at a Glance: Understanding Vehicle Taxes and Fees, https://www.onemotoring.com.sg/content/onemotoring/home/buying/upfront-vehicle-costs/taxstructure.html, diakses pada 26 Agustus 2020.

${ }^{37}$ Ibid.

${ }^{38}$ Skema cleaner fuels grants merupakan salah satu insentif pajak yang disediakan untuk mengurangi cukai atau bea masuk yang harus dibayar pengusaha (importir/produsen) untuk bahan bakar yang lebih bersih seperti biodiesel atau solar terbarukan. Lihat: Australian Governmet-Australian Tax Office, Fuel Scheme, https://www.ato.gov.au/Business/Fuel-schemes/, diakses pada 28 September 2020. 
dalam jangka waktu 3 tahun khususnya berkenaan dengan pajak alat berat. ${ }^{39}$ Peluang untuk melakukan perubahan terhadap UU a quo harus dimaknai bahwa dalam pemikiran dan penyusunan kerangka atau konsep pungutan alat berat yang lebih mengedepankan green economy ${ }^{40}$ atau ekonomi hijau. Model ekonomi hijau ini diyakini dapat mengurangi degradasi lingkungan dan efisiensi energi. ${ }^{41}$

Konsep pajak alat berat berdasarkan UU PDRD dengan nomenklatur Pajak Kendaraan Bermotor (PKB) dan Bea Balik Nama Kendaraan Bermotor (BBN-KB) mengandung misi pengelolaan lingkungan, akan tetapi misi ini terdegradasi dengan fungsi revenue-raising. ${ }^{42}$ Padahal penggunaan alat berat di kawasan pertambangan, perhutanan dan perkebunan berpotensi menimbulkan kerusakan lingkungan seperti kesaksian perwakilan pemerintah dalam Putusan Mahkamah Konstitusi Nomor 15/PUU-XV/2017 tentang uji materi Undang-Undang Nomor 28 Tahun 2009 tentang Pajak Daerah dan Retribusi Daerah yang menyatakan di Kalimantan Timur kerusakan hutan akibat penggunaan alat berat menyebabkan banjir setiap tahunnya dan merusak infrastruktur jalan dan jembatan yang memerlukan dana untuk perbaikan. Peristiwa kerusakan lingkungan yang serupa juga terjadi di Kalimantan Selatan akibat penggunaan alat berat. ${ }^{43}$ Dengan demikian, usulan kerangka atau konsep pajak alat berat di bawah ini merupakan titik awal bagi pembentuk undang-undang khusunya pemerintah untuk mempertimbangkan pemungutan yang mampu mengubah perilaku wajib pajak.

Berbicara konsep pajak yang mengarah pada perubahan perilaku perlu kembali pada prinsip polluter pays. Prinsip ini menegaskan tentang cost internalisation yang artinya seluruh biaya eksternalitas negatif yang disebabkan

39 Lihat poin 3 Amar Putusan Mahkamah Konstitusi Nomor 15/PUU-XV/2017 tentang uji materi Undang- Undang Nomor 28 Tahun 2009 tentang Pajak Daerah dan Retribusi Daerah.

${ }^{40}$ Green Economy adalah suatu model pendekatan pembangunan ekonomi yang mentransformasi kegiatan ekonomi menjadi lebih sehat lingkungan dan inklusif. Lihat dalam: Lucien Georgeson dan Mark Maslin, "The global green economy: a review of concepts, definitions, measurement methodologies and their interactions", Journal of Geo Geography and Environment, No. 1, Vol. Februari 2017, hlm. 4.

${ }^{41}$ R. Malar Maran dan Alexandru-Mircea Nedelea, "Green Economy: Challenges and Opportunities", Journal of Ecoforum, No, 3, Vol. 13, 2017, hlm. 1.

${ }^{42}$ Lihat bagian konsiderans Undang-Undang Nomor 28 Tahun 2009 tentang Pajak Daerah dan Retribusi Daerah.

43 Pendapat Saksi Presiden dalam Putusan Mahkamah Konstitusi Nnmor 15/PUU-XV/2017 tentang uji materi Undang-Undang Nomor 28 Tahun 2009 tentang Pajak Daerah dan Retribusi Daerah. 
oleh produksi dan/atau konsumsi dibebankan kepada pencemar. ${ }^{44}$ Dengan kata lain, pencemar dalam hal ini harus bertanggung jawab terhadap segala aktivitas ekonomi yang dilakukannya dan berpotensi merusak lingkungan.

Laporan Organisation for Economic Cooperation and Development (OECD) pada tahun 2001 menyatakan perlu adanya intervensi pemerintah dalam bentuk green tax reform dalam pengelolaan lingkungan. ${ }^{45}$ Tiga bentuk utama dalam green tax reform meliputi:

a. penghapusan subsidi;

b. restrukturisasi kebijakan pajak untukmeminimalisasi pencemaran; dan

c. penyusunan kebijakan pajak yang baru terkait dengan lingkungan. ${ }^{46}$

Ditinjau dari sisi intervensi kebijakan di bidang perpajakan, usulan konsep pajak bahan bakar (fuel taxes) dan biaya registrasi (registration fee) sebagai alternatif pungutan terhadap alat berat patut dipertimbangkan yang sekaligus termasuk ke dalam dalam dua bentuk green tax reform, yaitu: restrukturisasi kebijakan pajak dan penyusunan kebijakan pajak yang baru terkait dengan lingkungan.

Pertama, pajak bahan bakar (fuel taxes). Keberadaan pajak bahan bakar (fuel taxes) menjadi salah satu pungutan yang dapat dipertimbangkan untuk mengubah perilaku wajib pajak mengingat baik individu maupun industri sangat tergantung terhadap bahan bakar dalam aktivitas ekonominya. Pajak bahan bakar (fuel taxes) pada hakikatnya bukan merupakan jenis pajak yang baru, melainkan sudah diatur UU PDRD. Hal yang krusial dalam restrukturisasi pajak bahan bakar (fuel taxes) adalah penetapan dasar pengenaan (tax-base) dan tarif (tax-rate) yang mengakomodasi komponen-komponen eksternalitas negatif dari suatu produk.

Konstruksi pajak bahan bakar (fuel taxes) dalam UU PDRD yang berlaku saat ini dasar pengenaan pajaknya adalah Nilai Jual Bahan Bakar Kendaraan Bermotor sebelum dikenakan Pajak Pertambahan Nilai (PPN), sedangkan tarifnya ditetapkan maksimal sebesar $10 \% .47$ Tarif pajak yang ditetapkan dalam Peraturan Daerah

\footnotetext{
44 Organisation for Economic Co-operation and Development (OECD), Polluter Pays Principle, ParisFrance, 1992, hlm. 14.

45 Organisation for Economic Co-operation and Development (OECD), Environmentally Related Taxes in OECD Countries: Issues and Strategies, 2001, hlm. 33.

${ }^{46}$ Ibid.

${ }^{47}$ Pasal 18 juncto Pasal 19 ayat (1) Undang-Undang Nomor 28 Tahun 2009 tentang Pajak Daerah dan Retribusi Daerah.
} 
dapat diubah oleh Pemerintah dengan Peraturan Presiden. ${ }^{48}$ Apabila dicermati dasar pengenaan pajak (tax base) dan tarif pajak (tax rate) bahan bakar dalam UU PDRD tidak didapatkan penjelasan mengenai kriteria penetapan terkait lingkungan misalnya kandungan karbon, sulfur atau fosfor dalam bahan bakar yang digunakan. Sebagaimana telah dijelaskan di atas bahwa dasar pengenaan pajak (tax base) dan tarif pajak (tax rate) seharusnya terkait langsung dengan eksternalitas negatif yang ditimbulkan dalam penggunaan bahan bakar sehingga dapat mengubah perilaku masyarakat. Dengan demikian, restrukturisasi terhadap dasar pengenaan pajak (tax base) perlu dilakukan sehingga pajak bahan bakar ini mencerminkan upaya pemerintah untuk meminimalisir polusi yang ditimbulkan.

Penetapan dasar pengenaan pajak (tax base) perlu mempertimbangkan semua eksternalitas negatif yang mungkin timbul akibat penggunaan atau konsumsi bahan bakar. Emisi atau polutan dari bahan bakar seperti diesel dan bensin seharusnya diperhitungkan dalam penetapan dasar pengenaan pajaknya. Pertimbangan ini akan meningkatkan kapasitas dari pajak bahan bakar sehingga dapat mengubah perilaku individu maupun industri untuk mengurangi penggunaan atau konsumsi bahan bakar, bahkan bisa menyebabkan beralihnya pola penggunaan atau konsumsi ke produk yang lebih ramah lingkungan.

Pola yang sama dengan mempertimbangkan semua eksternalitas negatif seharusnya juga diimplementasi dalam menyusun tarif pajak bahan bakar. Skema restrukturisasi dapat dilakukan dengan membedakan tarif yang berlaku utamanya terhadap bahan bakar yang lebih ramah lingkungan. Pembedaan ini di beberapa negara seperti Denmark dan Norway mampu membawa dampak positif dengan berkurangnya penggunaan bahan bakar yang menimbulkan pencemaran terbesar terhadap lingkungan. ${ }^{49}$ Poin penting dalam restrukturisasi pajak bahan bakar (fuel taxes) adalah perlunya proses valuasi yang seksama dengan bantuan ahli yang menguasai secara teknis standar polluter pays principle wajib untuk dilakukan. Pada tataran implementatif tarif maupun dasar pengenaan pajak perlu

\footnotetext{
48 Pasal 19 ayat (3) Undang-Undang Nomor 28 Tahun 2009 tentang Pajak Daerah dan Retribusi Daerah

49 Organisation for Economic Co-operation and Development (OECD), Environmentally Related Taxes in OECD Countries: Issues and Strategies, Op. Cit., hlm. 35.
} 
dilakukan secara bertahap demi meminimalisir penolakan dari individu atau industri terutama terkait alat berat.

Praktik skema fuel tax credits di Australia dapat pula diadopsi di Indonesia dengan beberapa penyesuaian. Klaim kredit terhadap pajak bahan bakar dapat dimaknai sebagai insentif bagi industri alat berat untuk melakukan Research and Development (R\&D) sehingga menemukan alat yang membantu penghematan bahan bakar dan meningkatkan produktivitas serta mendorong penggunaan bahan bakar ramah lingkungan. Kebijakan kredit pajak bahan bakar perlu disusun secara cermat dengan memperhitungkan cost and benefits dari suatu kebijakan sehingga tidak menjadi kontra produktif dan menimbulkan ketidakefektifan perubahan perilaku dalam meminimalisir dampak lingkungan akibat penggunaan bahan bakar.

Kedua, biaya registrasi (registration fee). Salah satu bentuk dari green tax reform adalah menyusun kebijakan pajak yang baru dalam hal ini biaya registrasi (registration fee). Penyusunan kebijakan ini menarik apabila ditujukan pada emisi atau produk-produk yang dapat menimbulkan polusi pada lingkungan antara lain pupuk, pestisida atau baterai dan lain-lain. ${ }^{50}$ Menurut Organisation for Economic Cooperation and Development (OECD) biaya registrasi (registration fee) termasuk ke dalam pajak (taxes) dengan kategori pajak- pajak yang terkait dengan lingkungan dan dibebankan pada produk-produk terkait. ${ }^{51}$ Lebih lanjut Organisation for Economic Cooperation and Development (OECD) menyatakan bahwa pajak-pajak yang terkait dengan lingkungan dibedakan berdasarkan berat atau ukuran mesin. ${ }^{52}$ Padahal, pembedaan berdasarkan berat dan ukuran mesin dinyatakan tidak mendasarkan pada faktor terdekat dari dampak lingkungan atas penggunaan kendaraan. ${ }^{53}$

Penyusunan kebijakan pajak baru dalam konteks pungutan terhadap alat berat di Indonesia dapat mengadopsi biaya registrasi (registration fee) sebagaimana negara best practices, yaitu Australia dan Singapura. Nomenklatur pengenaan pungutan terhadap alat berat berat baik dalam bentuk biaya registrasi

\footnotetext{
${ }^{50}$ Ibid.

${ }^{51}$ Ibid.

${ }^{52}$ Ibid., hlm. 61.

${ }^{53}$ Ibid.
} 
(registration fee) atau pajak (tax) bukan menjadi persoalan yang berarti mengingat poin krusial yang dikedepankan adalah pengaruhnya terhadap perubahan perilaku. Penetapan dasar pengenaan dan tarif yang akan dikenakan terhadap alat berat harus memperhatikan polluter pays principle.

Penetapan dasar pengenaan dan tarif yang akan dikenakan terhadap alat berat dapat mempertimbangkan faktor terdekat dari dampak lingkungan atas penggunaan alat berat. ${ }^{4}$ Misalnya bagi alat berat yang tidak digunakan di jalan publik, maka dasar pengenaan dan tarif ditetapkan dengan memperhatikan eksternalitas negatif yang mungkin timbul akibat penggunaannya. Kriteria lain yang patut dipertimbangkan adalah emisi yang dihasilkan atau konsumsi bahan bakar sehingga alat berat yang menggunakan bahan bakar ramah lingkungan akan dikenakan tarif lebih rendah dibandingkan dengan yang tidak menggunakan bahan bakar ramah lingkungan.

Tarif yang akan dikenakan terhadap alat berat sepatutnya ditetapkan secara nasional sehingga terjadi keseragaman apabila pemungutannya dilimpahkan kepada Pemerintah Daerah. Berpijak pada praktik pengenaan biaya registrasi di Australia terdapat 4 kriteria pendaftaran yang digunakan meliputi: kendaraan berat baru terdaftar, kendaraan berat yang tidak terdaftar didaftarkan ulang, pendaftaran pada saat alat berat ditransfer ke daerah lain dan pelat nomor yang hilang, rusak, hancur atau dicuri diganti. Nomenklatur biaya registrasi (registration fee) atau pajak (tax) dapat berdiri sendiri dan terpisah dari Bea Balik Nama Kendaraan Bermotor (BBN-KB) apabila akan ditempatkan dalam perubahan UU PDRD mengingat alat berat bukan termasuk ke dalam kategori kendaraan bermotor pasca Putusan Mahkamah Konstitusi Nomor 3/PUUXIII/2015 tentang uji materi Undang- Undang Nomor 22 Tahun 2009 tentang Lalu Lintas dan Angkutan Jalan.

Tantangan yang Berpotensi Timbul dalam Penerapan Konsep Pungutan atas Alat Berat di Indonesia

Usulan restrukturisasi kebijakan pajak bahan bakar dan penyusunan kebijakan biaya registrasi (registration fee) atau pajak (tax) yang akan dikenakan 
terhadap alat berat secara normatif menimbulkan beberapa tantangan. Terdapat sedikitnya 3 tantangan baik dari sisi perubahan tujuan kebijakan, kapasitas kelembagaan dan alokasi penerimaannya yang turut berdampak pada implementasi kebijakan tersebut.

\section{a. Isu Penetapan Tujuan Pemungutan}

Desain kebijakan pemungutan pajak di Indonesia khususnya di level pemerintah daerah lebih ditujukan pada fungsi anggaran atau budgeter dalam hal ini digunakan sebagai alat untuk mengumpulkan dana bagi pengeluaranpengeluaran negara atau daerah.55 Apabila fungsi anggaran (budgeter) dikedepankan otomatis fungsi mengatur (regulerend) menjadi terdegradasi. Kondisi demikian terjadi pada jenis-jenis pajak di level pemerintah daerah yang terdapat dalam UU PDRD.

Peluang perubahan UU PDRD Tahun 2009 perlu disikapi dengan perubahan paradigma dari pembentuk UU atas tujuan utama pajak. Restrukturisasi pajak bahan bakar dan penyusunan kebijakan biaya registrasi (registration fee) atau pajak (tax) yang akan dikenakan terhadap alat berat apabila dimasukkan dalam rancangan perubahan, maka tujuan utama bukan hanya soal revenue-raising tetapi juga perlu penegasan bahwa beberapa jenis pajak mempunyai tujuan utama sebagai agent of change. ${ }^{56}$

Perubahan paradigma ini juga harus diikuti oleh para eksekutor pemungutan pajak di level pemerintah daerah sehingga efektivitas kebijakan dapat tercapai. Adolf Wagner sebagaimana dikutip oleh Santoso Brotodiharjo bahkan menyatakan semakin kecil hasil dari pajak dengan fungsinya yang bersifat mengatur maka semakin dekat dengan tujuan yang ditetapkan. ${ }^{57}$ Keberhasilan dari pajak dalam konteks restrukturisasi dan penyusunan kebijakan pajak yang lebih mengedepankan fungsi pengelolaan lingkungan dilihat dari semakin kecilnya penerimaan negara atau daerah. Artinya desain kebijakan pajak Daerah.

55 Lihat bagian konsiderans Undang-Undang Nomor 28 Tahun 2009 tentang Pajak Daerah dan Retribusi

56 Istilah agent of change merujuk pada pengetian suatu rancangan terencana yang berawal dari keputusan untuk melakukan upaya yang disengaja untuk memperbaiki sistem. Lihat dalam: Lippit, et al., sebagaimana dikutip oleh hlm. 24. Apabila dikatikan dengan pajak maka pajak difungsikan sebagai instrumen untuk memperbaiki sistem dalam hal ini maanfaat pajak sebagai alat pengelolaan lingkungan di daerah menjadi yang pokok dan pertama

${ }^{57}$ Santoso Brotodihardjo, 1995, Op. Cit., hlm. 213. 
tersebut tidak mengharapkan bertambahnya penerimaan sehingga mampu mengirimkan pesan yang benar kepada industri atau pengguna alat berat untuk berkontribusi dalam meminimalisir pencemaran sebagai akibat aktivitas ekonominya.

\section{b. Isu Kapasitas Institusi dan Administrasi}

Secara umum kapasitas institusi dan administrasi menjadi salah satu isu yang krusial dalam penyusunan dan implementasi kebijakan pajak. Isu tersebut timbul dalam dua bentuk green tax reform, yaitu restrukturisasi kebijakan pajak dan penyusunan kebijakan pajak baru terkait lingkungan. Syarat yang harus dipenuhi untuk mencapai efektivitas kebijakan adalah penetapan dasar pengenaan dan tarif yang mencerminkan semua biaya pencemaran yang timbul dalam aktivitas ekonomi.

Kondisi di atas, menimbulkan konsekuensi tersedianya otoritas pajak yang mempunyai kapasitas dan kemampuan untuk merancang dasar pengenaan dan tarif secara tepat. Data dan informasi yang akurat juga sangat diperlukan untuk mendukung valuasi dan penetapan dasar pengenaan dan tarif. Namun demikian, isu kurangnya kapasitas institusi/otoritas pajak seringkali timbul sebagai akibat kurangnya data dan informasi yang diperlukan untuk memperkirakan potensi dasar pengenaan dan tarif.

Akses terhadap data dan informasi yang reliable dapat dilakukan dengan melibatkan pihak-pihak eksternal. Salah satunya dengan membangun dialog pada level pemerintahan tingkat tinggi dan mengembangkan diskusi berdasarkan data serta analisis yang akurat. ${ }^{8}$ Peningkatan kapasitas otoritas pajak juga dapat dilakukan dengan mengikuti pelatihan untuk meningkatkan keterampilan teknis yang dibutuhkan. ${ }^{59}$ Kerjasama dengan berbagai pihak yang dapat memberikan bantuan teknis diperlukan untuk mempermudah pengumpulan informasi secara teratur dan sekaligus memverifikasinya sehingga dapat meminimalisir ketidakakuratan valuasi.

58 International Monetary Fund (IMF), Organisation for Economic Co-operation and Development (OECD), United Nations (UN), World Bank Group (WBG), Enhancing the Effectiveness of External Support in Building Tax Capacity in Developing Countries, Report Prepared for Submission to G20 Finance Ministers, July 2016, hlm. 10.

$$
59 \text { Ibid. }
$$


Isu lain yang muncul adalah ketidaksiapan administrasi perpajakan dalam implementasi green tax reform sehingga dapat menghambat tercapainya tujuan pajak sebagai agent of change. Carlos A. Silvani sebagaimana dikutip oleh Devano dan Rahayu menyebutkan bahwa administrasi pajak dikatakan baik apabila dapat mengatasi antara lain wajib pajak yang tidak terdaftar dan penyelundup pajak. ${ }^{60}$ Dengan kata lain, fungsi pengawasan (controlling) dan penegakan hukum (law enforcement) perlu diterapkan secara tegas dan konsisten untuk menjamin perlakuan yang adil bagi wajib pajak. Hal ini diperkuat dengan laporan World Bank 2005 yang menyatakan bahwa secara umum industri akan menerima kebijakan pajak yang baru jika otoritas mempunyai kapasitas untuk memperlakukan semua wajib pajak secara adil di mana kompetitor yang melakukan kecurangan dapat terdeteksi dan dikenakan sanksi yang seharusnya. ${ }^{61}$

\section{c. Isu Penerimaan Publik}

Usulan green tax reform pada alat berat kemungkinan akan menuai reaksi beragam dari publik terutama industri. Kebijakan pajak bukan hal yang mudah untuk diterima oleh masyarakat. Penyesuaian atas dasar pengenaan pajak dan tarif pajak saja tidak serta merta diterima dengan baik apalagi usulan kebijakan baru atas pungutan terhadap alat berat sudah barang tentu akan susah diterima secara skeptis.

Publik akan mempertanyakan tujuan atau motif sebenarnya dari green tax reform yang dilakukan pemerintah: apakah memang dilakukan murni untuk agent of change ataukah utamanya untuk revenue-raising seperti halnya yang terjadi pada cukai di Indonesia. Cukai menempatkan fungsi mengatur (regulerend) sebagai yang utama karena pungutan ini ditujukan untuk mengendalikan konsumsi dan dampak pemakaian produk tertentu pada lingkungan serta masyarakat. Akan tetapi, pada kenyataannya fungsi tersebut tidak tercapai dengan baik yang terefleksi dari penerimaan cukai di Indonesia yang semakin meningkat dari tahun ke tahun.

Laporan Organisation for Economic Co-operation and Development (OECD) 2010 menyatakan bahwa ecological tax reform di sejumlah negara-negara Eropa tidak berjalan dengan lancar dan mengalami hambatan pada saat akan

${ }^{60}$ Sony Devano dan Siti Kurnia Rahayu, Op. Cit., hlm .72-73.

61 World Bank, Environmental Fiscal Reform: What should be done and How to achieve it, The World Bank Organization, Washingthon DC, USA, 2005, hlm. 81 - 82. 
diimplementasikan.62 Kurangnya pemahaman terhadap keseluruhan skema kebijakan dan kurangnya kepercayaan publik terhadap penggunaan pendapatan dari pajak terkait lingkungan ini menjadi batu sandungan reformasi yang dilakukan. ${ }^{63}$ Terdapat dua pendekatan untuk meningkatkan penerimaan publik atas kebijakan pajak yang diluncurkan meliputi:

1. Membangun pemahaman yang sama atas keseluruhan skema kebijakan. ${ }^{64}$ Hal ini dapat dilakukan dengan melibatkan para pihak terkait, termasuk industri dalam mempersiapkan kebijakan pajak dan memberikan informasi serta sosialisasi kepada publik atas kebijakan yang diambil melalui berbagai media.

2. Menerapkan kebijakan pajak secara bertahap. ${ }^{65}$ Misalnya saja pada restrukturisasi kebijakan yang menyebabkan kenaikan tarif pajak dilakukan secara bertahap sehingga memberikan waktu yang cukup kepada publik atau industri beradaptasi dengan kebijakan tersebut sekaligus mencari substitusi produk yang lebih ramah lingkungan.

\section{Penutup}

Penelitian ini menyimpulkan bahwa: pertama, usulan konsep pungutan terhadap alat berat pasca Putusan Mahkamah Konstitusi Nomor 15/PUUXV /2017 tentang uji materi Undang-Undang Nomor 28 Tahun 2009 tentang Pajak Daerah dan Retribusi Daerah diarahkan pada restrukturisasi kebijakan pajak bahan bakar dan penyusunan kebijakan pajak dalam bentuk registration fee yang dikenakan terhadap alat berat. Kedua bentuk green tax reform ini menggunakan basis polluter pays principles yang penetapan dasar pengenaan dan tarif harus mencerminkan full social cost dari aktivitas ekonomi yang dilakukan dan berpotensi mencemarkan lingkungan. Dasar pengenaan dan tarif dari pajak bahan bakar tersebut harus didesain sedekat mungkin dengan eksternalitas negatif yang mungkin timbul. Ketepatan dalam valuasi dan penetapan dapat mengubah perilaku pengguna atau industri untuk melakukan upaya efisiensi energi dan mencari substitusi produk ramah lingkungan.

\footnotetext{
${ }^{62}$ Organisation for Economic Co-operation and Development (OECD), Taxation, Innovation and The Environment, 2010, hlm. 146.

${ }^{63}$ Ibid.

${ }^{64}$ Organisation for Economic Co-operation and Development (OECD), The Political Economy of Environmentally Related Taxes, Op. Cit., hlm. 153.

${ }^{65}$ Ibid.
} 
Kedua, tantangan utama atas usulan konsep pungutan alat berat di Indonesia terdiri dari 3 hal, yaitu isu penetapan tujuan pemungutan, kapasitas institusi dan administrasi serta penerimaan publik. Ketiga isu tersebut apabila tidak mendapat perhatian dari pembentuk UU akan menghambat efektivitas kebijakan. Beberapa pendekatan yang dapat digunakan untuk mengatasi persoalan tersebut antara lain mengubah paradigma legislator dan eksekutor bahwa tujuan kebijakan diutamakan pada fungsinya sebagai agent of change, meningkatkan kapasitas institusi serta administrasi perpajakan, dan penerapan kebijakan secara bertahap.

\section{Daftar Pustaka}

\section{Buku}

Brotodihardjo, Santoso, Pengantar Ilmu Hukum Pajak, Eresco Bandung, 1995.

Creswell, John W., Research Design: Qualitative and Quantitative Approach, Sage Publication, London, 1994.

Devano, Sonydan Siti Kurnia Rahayu, Perpajakan: Konsep, Teori dan Isu, Prenada Media Group, Jakarta, 2006.

Maatta, Kalle, Environmental Taxes: An Introductory Analysis, Edwar Elgar Publishing Limited, 2006.

Sumardjono, Maria SW., Pedoman Pembuatan Usulan Penelitian, Gramedia Pustaka Utama, Jakarta, 1997.

\section{Jurnal}

Andrew J. White, "Decentralised Environmental Taxation in Indonesia: A Proposed Double Dividend for Revenue Allocation and Environmental Regulation", Journal of Environmental Law, No. 1, Vol. 19, 2007.

Carlo Gerwing, "Meaning of Change Agent within Organizational Change", Journal of Applied Leardership Management, Vol. 4, 2016.

Lucien Georgeson, dan Mark Maslin, "The global green economy: a review of concepts, definitions, measurement methodologies and their interactions", Journal of Geo Geography and Environment, No. 1, Vol. Februari 2017.

Neha Pathakji, "Slippery Slopes of Compensatory Tax and Fee", Journal of the Indian Law Institute, No. 1, Vol. 56, Maret 2014.

Ni Nyoman Tanti Parwati dan I Wayan Parsa, "Implikasi Yuridis Putusan Mahkamah Konstitusi Nomor 15/PUU-XV/2017 Terhadap Alat Berat Sebagai Obyek Pajak Ganda", Jurnal Ilmu Hukum, No. 3, Vol. 7, Februari 2019. 
Puja Rizqy R. dan Abdul Hasyim B., “Analisis Kontribusi Pemungutan Pajak Alat-Alat Berat dalam Meningkatkan PAD di Provinsi Sumatera Utara", Jurnal Perpajakan, No. 2, Vol. 1, 2020.

R. Malar Maran dan Alexandru-Mircea Nedelea, “Green Economy: Challenges and Opportunities", Journal of Ecoforum, No, 3, Vol. 13, 2017.

\section{Artikel}

International Monetary Fund (IMF), Organisation for Economic Co-operation and Development (OECD), United Nations (UN), World Bank Group (WBG), Enhancing the Effectiveness of External Support in Building Tax Capacity in Developing Countries, Report Prepared for Submission to G20 Finance Ministers, July 2016.

Organisation for Economic Co-operation and Development (OECD), Environmentally Related Taxes in OECD Countries: Issues and Strategies, 2001.

Organisation for Economic Co-operation and Development (OECD), Polluter Pays Principle, Paris-France, 1992.

Organisation for Economic Co-operation and Development (OECD), Taxation, Innovation and The Environment, 2010

Organisation for Economic Co-operation and Development (OECD), The Political Economy of Environmentally Related Taxes, 2006.

World Bank, 2005, Environmental Fiscal Reform: What should be done and How to achieve it, The World Bank Organization, Washingthon DC, USA

\section{Skripsi}

Aditya, Muhammad Fauzi, 2019, Efektivitas Pelaksanaan Pemungutan Pajak Kendaraan Bermotor Khusus Alat Berat Dan Alat Besar Di Kabupaten Temanggung, Skripsi, Fakultas Hukum Universitas Gadjah Mada.

\section{Internet}

A Singapore Government Agency Website, at a Glance: Understanding Vehicle Taxes and Fees, https://www.onemotoring.com.sg/content/onemotoring/home/buying /upfront- vehicle-costs/tax-structure.html, diakses pada tanggal 26 Agustus 2020.

Alayidrus, Hadijah, Pajak Alat Berat: Pemerintah Tetap Pungut Pajak Selama Masa Transisi, https://finansial.bisnis.com/read/20171012/10/ 698647/pajak-alat-berat-pemerintah- tetap-pungut-pajak-selama-masatransisi, diakses pada 3 April 2020.

Australian Governmet-Australian Tax Office, Fuel Scheme, https://www.ato.gov.au/Business/Fuel-schemes/, diakses pada tanggal 28 September 2020. 
Australian Taxation Office, Heavy Vehicles, https://www.ato.gov.au/ printfriendly.aspx?url=/Business/Fuel-schemes/In- detail/Heavyvehicles/, diakses pada tanggal 26 Agustus 2020.

Cumberland County, Heavy Equipment, http://www.co.cumberland.nc.us/ departments/tax-group/tax/business-property/special-sales-tax/heavyequipment, diakses pada 18 Agustus 2020.

Koran Kaltara, 2019, BPPRD Akui Kesulitan Menarik Pajak Alat Berat, http:/ / korankaltara.com/bpprd-akui-kesulitan-menarik-pajak-alatberat/, diakses pada akses 3 April 2020.

NHVR, National Heavy Vehicle Plates, https://www.nhvr.gov.au/roadaccess/registration/national-heavy-vehicle-plates, diakses pada tanggal 26 Agustus 2020.

Nur, Choirunnissa, Melimpah Kendaraan Melimpah Pendapatan, https:/ /lokadata.id/artikel/melimpah-kendaraan-melimpahpendapatan, diakses pada 3 April 2020.

Sahbani, Agus Pembentuk UU Diminta 'Rombak' Pengaturan Pajak Alat Berat, https://www.hukumonline.com/berita/baca/lt59dc955430b47/pembent uk-uu-diminta- rombak-pengaturan-pajak-alat-berat, diakses pada 3 April 2020.

South Australia, Heavy Vehicle Registration Scheme, diunduh dari https://www.sa.gov.au/topics/driving-and-transport/heavyvehicles/registering-a-heavy- vehicle/heavy-vehicle-registration-scheme, diakses 26 Agustus 2020.

\section{Peraturan Perundang-Undangan}

Undang-Undang Nomor 28 Tahun 2009 tentang Pajak Daerah dan Retribusi Daerah (Lembaran Negara Republik Indonesia Tahun 2009 Nomor 130).

\section{Putusan Pengadilan}

Putusan Mahkamah Konstitusi Nnmor 15/PUU-XV/2017 tentang uji materi Undang-Undang Nomor 28 Tahun 2009 tentang Pajak Daerah dan Retribusi Daerah.

Putusan Mahkamah Konstitusi Nomor 3/PUU-XIII/2015 tentang uji materi Undang-Undang Nomor 22 Tahun 2009 tentang Lalu Lintas dan Angkutan Jalan 